\title{
Hospitalization of children under five years of age due to avoidable causes
}

\author{
Rosana Rosseto de Oliveira ${ }^{1}$ \\ Josane Rosenilda da Costa $^{1}$ \\ Thais Aidar de Freitas Mathias ${ }^{2}$
}

This study characterizes the profile of hospital morbidity according to the main diagnosis upon admission, in individuals younger than five years old, residents of three cities (Maringá, Sarandi and Paiçandu) in the Paraná state, Brazil. Information contained in hospital admission forms from 1998 to 2009 was used. The hospitalizations of 41,220 individuals younger than five years old were analyzed. The results indicate a decline of $16.1 \%$ in hospital admissions of patients younger than five years old in relation to the total number of admissions in all age groups. As for the main diagnoses, there were diseases of the respiratory system (55.6\%), infectious and parasitic diseases $(14.8 \%)$ and diseases originating in the perinatal period $(12.9 \%)$. Such conditions can be avoided by implementing primary health care measures, which shows the need to intensify the actions recommended by the programs directed to child health.

Descriptors: Hospitalization; Child, Hospitalized; Child Health.

\footnotetext{
${ }^{1}$ RN, Master's Student in Nursing, Universidade Estadual de Maringá, PR, Brazil. E-mail: Rosana rosanarosseto@gmail.com, Josane josanerc@hotmail.com.

${ }^{2}$ RN, Ph.D. in Public Health, Adjunct Professor, Universidade Estadual de Maringá, PR, Brazil. E-mail: tafmathias@uem.br.
}

Corresponding Author:

Thais Aidar de Freitas Mathias

Universidade Estadual de Maringá. Departamento de Enfermagem

Av. Colombo, 5790

Zona 07

CEP: 87020-900, Maringá, PR, Brasil

E-mail: tafmathias@uem.br 


\section{Hospitalizações de menores de cinco anos por causas evitáveis}

O estudo objetivou caracterizar o perfil da morbidade hospitalar, segundo diagnóstico principal de internação, em menores de cinco anos, residentes em municípios do Estado do Paraná: Maringá, Sarandi e Paiçandu. Foram utilizadas informações registradas nos formulários de Autorização de Internação Hospitalar, para os anos de 1998 a 2009. Analisaram-se 41.220 internações de menores de 5 anos. Os resultados evidenciam declínio de $16,1 \%$ de internações de menores de cinco anos, em relação ao total de internações de todas as faixas de idade. Quanto às principais causas de hospitalização, foram evidenciadas as doenças do aparelho respiratório (55,6\%), doenças infecciosas e parasitárias $(14,8 \%)$ e afecções originadas no período perinatal $(12,9 \%)$, condições essas evitáveis por medidas de atenção básica, sinalizando a necessidade de intensificação das ações preconizadas pelos programas voltados à saúde da criança.

Descritores: Hospitalização; Criança Hospitalizada; Saúde da Criança.

\section{Hospitalizaciones en menores de cinco años por causas evitables}

El objetivo de este estudio fue caracterizar el perfil de la morbilidad hospitalaria según el diagnóstico principal de internación, en menores de cinco años, residentes en las ciudades de Maringá, Sarandi y Paiçandu. Fueron utilizadas informaciones registradas en los formularios de Autorización de Internación Hospitalaria, en los años de 1998 a 2009. Se analizaron 41.220 internaciones en menores de 5 años. Los resultados evidencian una disminución de $16,1 \%$ de internaciones de menores de cinco años en relación al total de internaciones en todos los intervalos de edad. En cuanto a las principales causas de hospitalización se encontraron las enfermedades del aparato respiratorio $(55,6 \%)$, enfermedades infecciosas y parasitarias $(14,8 \%)$ y afecciones originadas en el período perinatal (12,9\%); estas enfermedades pueden evitadas con medidas de atención básica, señalando la necesidad de intensificar las acciones preconizadas por los programas dirigidos a la salud del niño.

Descriptores: Hospitalización; Niño Hospitalizado; Salud del Niño.

\section{Introduction}

The Pact for Health recommends gradually reducing neonatal mortality by $5 \%$ a year. In 2006, there was a reduction of $50 \%$ and $20 \%$ in the mortality rate of children younger than five years old due to diarrheal diseases and pneumonia, respectively, diseases that are considered to be evitable ${ }^{(1-2)}$. The Pact for Health also recommends the creation of committees to monitor child mortality in at least $80 \%$ of the cities with more than 80,000 inhabitants $^{(2)}$. Hence, states and cities should monitor the health of the infant population and identify the profile of hospitalizations among children. They should also help to identify the health needs of the population, in general, and of this group in particular, to support the implementation of actions to fight these causes.
The rates of hospitalization classified by diagnosis are important indicators of quality of life and outpatient problem-solving capacity and serve to monitor the achievement of the goals envisaged by the Pact for Health. Studies using these indicators have enabled the improvement of actions and public policies capable of reducing this traumatic event for the child and family ${ }^{(3-4)}$. The high frequency of hospitalizations due to diseases considered to be easily preventable, which can be diagnosed and treated, reflect both a lack of appropriate care delivery to certain groups of the population, as well as their poor life and health conditions ${ }^{(4)}$.

Measures to reduce deaths that can be avoided through interventions from the Single Health System (SUS) directed to children younger than five years of 
age include: immune prevention actions, appropriate care provided to women during pregnancy and childbirth and to newborns, appropriate diagnosis and treatment and health promotion ${ }^{(1)}$. Therefore, it is expected that the occurrence of hospitalizations due to avoidable causes will be controlled and in decline in cities with planed health care systems where outpatient care is appropriate and accessible to the population.

The Brazilian Ministry of Health has identified a considerable reduction of child hospitalizations after the implementation of the Family Health Strategy (FHS), especially in regard to systematic monitoring activities and ensured access to health services for children with acute problems. As a result, hospitalizations of children younger than five years old due to pneumonia and dehydration decreased 33\%. This percentage was $17.55 \%$ and $11.67 \%$ of the total number of hospitalizations among the population covered by the $\mathrm{FHS}^{(5)}$ in 1999 and 2001, respectively. Another measure to monitor and improve child health involves the List of Primary Health Care Indicators approved by the Ministry of Health, among which hospitalizations due to respiratory and diarrheal diseases in children younger than five years old are indicators that should be agreed upon by states and cities $^{(6)}$.

Studies addressing hospital morbidity in Brazil are possible through the use of the SUS Hospital Information System (SUS-HIS). Even though the system is intended to pay public and private hospitals linked to the SUS, data concerning hospitalizations such as diagnosis, gender, age, city of residence, average duration of hospitalization, expenditure and hospital morbidity are useful in epidemiological studies designed to improve knowledge produced in the field of health(7).

Considering the Pact for Health's recommendations with an emphasis on the reduction of maternal and child mortality, and considering the existence of inequalities and areas with vulnerable populations, it is necessary to identify the behavior of the main indicators of child health to achieve the expected goals. Hence, hospitalizations should be monitored, especially those due to respiratory infections and diarrheal diseases in children younger than five years old. This study characterizes the profile of hospital morbidity according to age and the main diagnosis of hospitalization in children younger than five years old, living in three cities of the state of Paraná, Brazil (Maringá, Sarandi and Paiçandu) between 1998 and 2009.

\section{Method}

This descriptive and exploratory study addresses hospitalizations of residents in Maringá, Sarandi, and Paiçandu from 1998 to 2009. The city of Maringá is located in the northeast of Paraná with a population of 357,077 inhabitants in 2010; 4,232 were younger than five years of age. With a rate of urbanization of 98.2\% and Human Development Index (HDI) of 0.84 in $2000^{(8)}$, the city has 25 primary health care units, three referral units (Integrated Mental Health Center, Psychosocial Care Center II, and Psychosocial Care Center for Alcohol and Drugs), the Center for Dental Specialties, in addition to 13 hospitals, two of which are public hospitals. None are exclusively child-friendly hospitals. Maringá hosts the $15^{\text {th }}$ Health Region in the State of Paraná and the Metropolitan Region of Maringá and is a care provider of reference for the neighboring cities, including for child hospitalization requiring a greater level of complexity.

The metropolitan region of Maringá is composed of 13 cities but only the cities of Maringá, Paiçandu, and Sarandi present a high level of integration involving inter-municipal flow, functional complementarity, and socio-economic integration, in addition to being conurbated. Conurbanization is defined as an urban agglomeration between two or more cities that results in increased urbanization and geographic growth in which the areas of the cities increase and become confounded with neighbor cities $^{(9)}$. Sarandi, a city linked to Maringá to the east has a total area of $103 \mathrm{~km}^{2}$ and had an estimated population of 82,847 in 2010 . Sarandi presents the greatest population density in the metropolitan region of Maringá, at 816 inhabitants per $\mathrm{km}^{2}$, with an urbanization rate of $99.1 \%$ and HDI 0.76 in 2000, which is considered average ${ }^{(8)}$. Paiçandu is the smallest studied city, linked to Maringá to the west with a total population of 35,936 in 2010; its rate of urbanization is $98.6 \%$ and HDI of 0.74 in 2,000 , also considered to be average ${ }^{(8)}$.

Information contained in the forms processed by SUS/HIS between 1998 and 2009 and available on the Internet from the DATASUS ${ }^{(10)}$ site, was used in this study. These databases present information concerning hospital care delivered to patients cared for in the public health system, such as the patient's city of residence and the city where the patient was hospitalized; main and secondary diagnoses of hospitalization; data on 
mortality; age; gender; and expenditure on health care. Data from the resident population by age group, used for the coefficients computation, were also extracted from the DATASUS's site.

We note that some factors can influence the quality of clinical data concerning the hospitalizations contained in the system. Information concerning diagnoses and the characteristics of hospitalized patients may be poorly noted in the medical files, present coding errors or illegible medical notations, due to a lack of training, non-adherence of the employees to the coding rules, and various diagnoses in the same hospitalization ${ }^{(11)}$.

Hospital morbidity was analyzed by age, main diagnosis in the hospitalization, and city of residence. The diagnoses were analyzed by chapters and groups of the International Classification of Disease $-10^{\text {th }}$
Review (ICD-10), using absolute and relative numbers and the coefficient of hospitalization. The coefficient of hospitalization estimates the risk of hospitalization and was computed for 1,000 children from zero to five years old, resident in each city by year of occurrence ${ }^{(6)}$. The research project was approved by the Ethics Committee Concerning Research with Human Subjects at the State University of Maringá (protocol No. 163/2010).

\section{Results}

A total of 41,220 hospitalizations among children younger than five years old occurred from 1998 to 2009 in the three cities. There was a decrease of $16.1 \%$ in the hospitalization coefficient (Figure 1), which was most expressive in Paiçandu (-40.3\%).

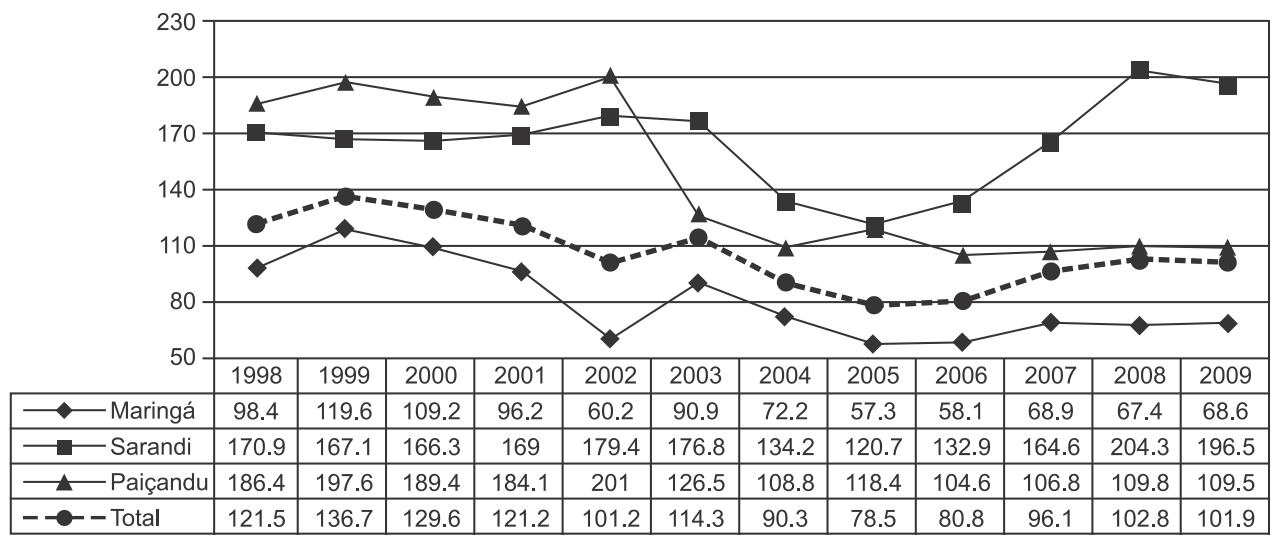

Source: Brazilian Ministry of Health. DATASUS. http://tabnet.datasus.gov.br/cgi/deftohtm.exe?sih/cnv/mrpr.def

Figure 1 - Coefficient of hospitalization per 1,000 children younger than five years old according to year. Maringá, Sarandi and Paiçandu, PR, Brazil - 1998 to 2009

Figure 2 presents the tendency of the coefficients according to the main diagnosis of the hospitalization and Table 1 shows that respiratory tract diseases were the most frequently observed with $54.6 \%$ of the total of hospitalizations in 2009, followed by infectious and parasitic diseases and perinatal diseases, with $14.5 \%$ and $12.6 \%$, respectively. The coefficient of hospitalization was always smaller for Maringá, both for respiratory diseases and infectious and parasitic diseases, during the entire studied period (Figure 2).

When hospitalizations were analyzed only for 2009, respiratory system diseases, infectious and parasitic diseases and those originating in the perinatal period represented $81.7 \%$ of the hospitalizations. These diseases accounted for $72 \%$ of hospitalizations among children living in Maringá, 92.1\% for those in Sarandi and $87.5 \%$ for Paiçandu residents (Table 1). Among diseases in the respiratory system, influenza and pneumonia stood out with $72.1 \%$; intestinal diseases were the most frequent with $34.6 \%$ among the infectious and parasitic diseases; hospitalizations due to perinatal causes represented $20.9 \%, 6.1 \%$ and $4.2 \%$ in Maringá Sarandi and Paiçandu, respectively (Table 1 ). 
Coeff.

Perinatal

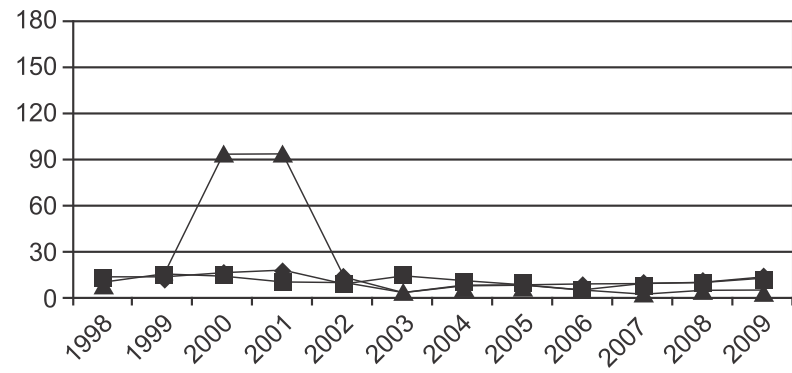

Coeff.

Infectious and Parasitic Diseases

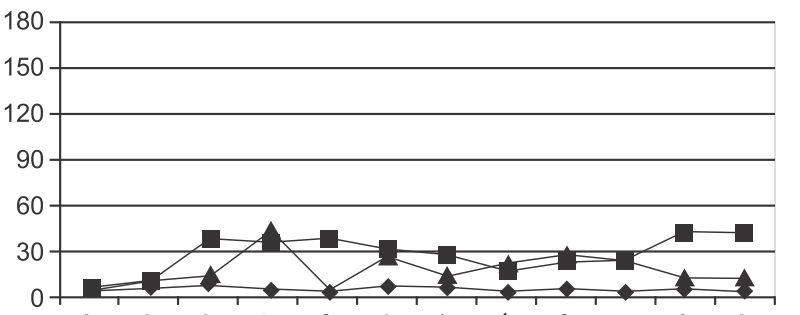

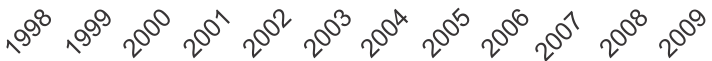

Coeff.

Respiratory System Diseases

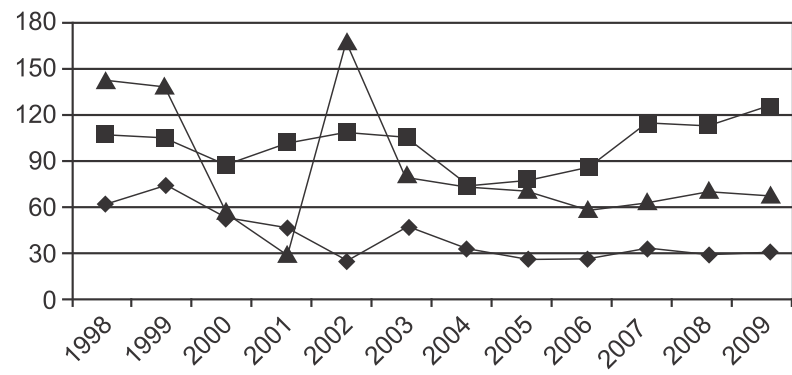

Coeff.

Other Causes

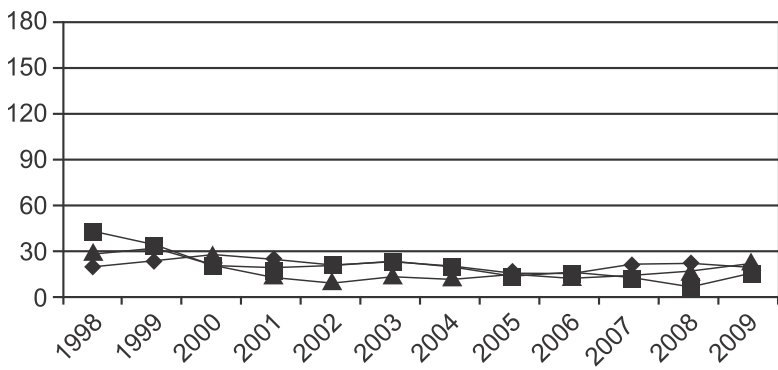

$$
\multimap \text { Maringá } \multimap \text { Sarandi Paiçandu }
$$

Source: Brazilian Ministry of Health. DATASUS (http://tabnet.datasus.gov.br/cgi/deftohtm.exe?sih/cnv/mrpr.def)

Figure 2 - Coefficient of hospitalization per 1,000 children younger than five years of age according to diagnosis and year. Maringá, Sarandi and Paiçandu, PR, Brazil - 1998 to 2009

Table 1 - Hospitalizations among children younger than five years old (number, percentage and coefficient per 1,000 children) according to diagnosis for hospitalization and city. Maringá, Sarandi and Paiçandu, PR, Brazil, 2009

\begin{tabular}{|c|c|c|c|c|c|c|c|c|c|c|c|c|}
\hline \multirow{2}{*}{ Diagnosis } & \multicolumn{3}{|c|}{ Maringa } & \multicolumn{3}{|c|}{ Sarandi } & \multicolumn{3}{|c|}{ Paiçandu } & \multicolumn{3}{|c|}{ Total } \\
\hline & $\mathbf{N}^{\circ}$ & $\%$ & coef & $\mathbf{N}^{\circ}$ & $\%$ & coef & $\mathbf{N}^{\circ}$ & $\%$ & coef & $\mathbf{N}^{\circ}$ & $\%$ & coef \\
\hline Respiratory & 552 & $43.4^{*}$ & 29.8 & 795 & 64.1 & 126.0 & 181 & 62.8 & 68.8 & 1528 & 54.6 & 55.6 \\
\hline Influenza (flu) and pneumonia & 335 & 60.7 & 18.1 & 699 & 87.9 & 110.8 & 68 & 37.6 & 25.8 & 1102 & 72.1 & 40.1 \\
\hline Chronic diseases in the lower airway & 106 & 19.2 & 5.7 & 67 & 8.4 & 10.6 & 87 & 48.1 & 33.1 & 260 & 17 & 9.5 \\
\hline Acute infections in the upper airway & 73 & 13.2 & 3.9 & 10 & 1.3 & 1.6 & 22 & 12.2 & 8.4 & 105 & 6.9 & 3.8 \\
\hline Other respiratory diseases & 38 & 6.9 & 2.0 & 19 & 2.4 & 3.0 & 4 & 2.2 & 1.5 & 61 & 4 & 2.2 \\
\hline Infectious and Parasitic diseases & 98 & 7.7 & 5.3 & 272 & 21.9 & 43.1 & 37 & 12.8 & 14.1 & 407 & 14.5 & 14.8 \\
\hline Intestinal infectious diseases & 34 & 34.7 & 1.8 & 114 & 41.9 & 18.1 & - & - & - & 148 & 36.4 & 5.4 \\
\hline $\begin{array}{l}\text { Viral infections, skin and mucosa } \\
\text { lesions }\end{array}$ & 8 & 8.2 & 0.4 & 83 & 30.5 & 13.2 & - & - & - & 91 & 22.4 & 3.3 \\
\hline Other infectious and parasitic & 56 & 57.1 & 3.0 & 75 & 27.6 & 11.9 & 37 & 100 & 14.1 & 168 & 41.3 & 6.1 \\
\hline Perinatal & 266 & 20.9 & 14.3 & 76 & 6.1 & 12.0 & 12 & 4.2 & 4.6 & 354 & 12.6 & 12.9 \\
\hline $\begin{array}{l}\text { Respiratory and cardiovascular } \\
\text { disorders in the perinatal period }\end{array}$ & 112 & 42.1 & 6.0 & 28 & 36.8 & 4.4 & 7 & 58.3 & 2.7 & 144 & 40.7 & 5.2 \\
\hline $\begin{array}{l}\text { Disorders during pregnancy and fetal } \\
\text { growth }\end{array}$ & 69 & 25.9 & 3.7 & 17 & 22.4 & 2.7 & - & - & - & 93 & 26.3 & 3.4 \\
\hline Other perinatal diseases & 85 & 32.0 & 4.6 & 31 & 40.8 & 4.9 & - & - & - & 117 & 33.1 & 4.3 \\
\hline Other causes & 356 & 28.0 & 19.2 & 97 & 7.8 & 15.4 & 58 & 20.1 & 22.0 & 511 & 18.3 & 18.6 \\
\hline Total & 1272 & 100 & 68.6 & 1240 & 100 & 196.5 & 288 & 100 & 109.5 & 2800 & 100 & 101.9 \\
\hline
\end{tabular}

Source: Ministry of Health. DATASUS.(http://tabnet.datasus.gov.br/cgi/deftohtm.exe?sih/cnv/mrpr.def)

*Percentage calculated in relation to the total of hospitalization for each age in 2009. 


\section{Discussion}

This study's results are consonant with those found in the literature in relation to causes of hospitalizations, that is, diseases in the respiratory system, infectious and parasitic diseases and those that originate during the perinatal period are the most frequent diseases demanding health services among children up to five years old in developing countries ${ }^{(12-13)}$. A study conducted in Brazil also showed that respiratory, infectious and parasitic diseases are the most frequent causes of hospitalization, $40.3 \%$ and $21.6 \%$ respectively, with an emphasis on the North and Northeast where these percentage are even higher(14).

The high percentage and coefficients of hospitalization found in this study raise a red flag requiring mechanisms of analysis and a search for potential explanations for their occurrence. Various studies show that high rates of hospitalizations due to diseases sensitive to primary care measures are associated with deficient coverage by services and/ or low problem-solving capacity regarding certain health conditions, indicating the poor quality of health services $^{(15-16)}$.

Diarrheal diseases still persist worldwide as a remarkable population health problem despite advancements achieved in preventing its primary complication, dehydration, through oral rehydration solutions in use since the $1980 \mathrm{~s}^{(17)}$. Diarrheal diseases still are the primary cause of death among children from one to four years old in many countries. It implies a considerable load of morbidity and mortality and consequently a considerable demand for the health services due to the pathogenic path that results from a set of various economic, social, cultural and biological factors, which can occur and progress differently in various regions and populations. Diarrheal diseases have decreased in Brazil from 11.9/1,000 live births in 1980 to $0.2 / 1,000$ births in $2000^{(18)}$. Disparities are also found at a national level among different regions. Diarrhea accounts for $30 \%$ of the total deaths in the first year of life in the Northeast, four to five times greater than that observed in the South. We acknowledge, however, that due to the advancements achieved in the management of the disease and improved basic sanitation, drinking water, and hygiene habits, diarrheal diseases have given way to respiratory diseases, which is currently the leading type of disease causing hospitalization and death among children younger than five years old ${ }^{(19)}$.

The causes of hospitalization during the perinatal period include respiratory disorders, delayed fetal growth, malnutrition, and disorders associated with preterm pregnancies, which in return result in low birth weight, conditions originating in the perinatal period, congenital infections, intrauterine hypoxia and neonatal asphyxia, which are generally associated with the quality of care provided to pregnant women, during childbirth and to newborns.

These results indicate the need to intensify actions recommended by the programs focused on child health, since these are diseases sensitive to primary care, that is, they represent a set of health conditions to which an effective action implemented at the primary health care level would reduce the risk of hospitalization(15). It is important to acknowledge the existence of inequalities even among neighboring cities, as is the case in this study. Very high coefficients of hospitalization were observed in Sarandi and Paiçandu, especially in Sarandi, mostly in relation to hospitalization due to flu and pneumonia. Maringá presented a coefficient of 18.1 and Paiçandu presented a coefficient of 25.8, while hospitalizations reached 110.8 hospitalizations per 1,000 children younger than five years old in Sarandi (Table 1), that is, 6.1 times greater than in Maringá and 4.3 times greater than the observed in Paiçandu.

Even though the Maringá metropolitan area is composed of 13 cities, only Sarandi and Paiçandu present a high level of socioeconomic and demographic integration with Maringá(9). This dependency is demonstrated by the percentage of the population working in Maringá. A total of $50.4 \%$ from the population economically active in Sarandi and $60.4 \%$ from Paiçandu, work in companies in Maringá, in addition to students who commute to schools in Maringá(20). Additionally, Sarandi and Paiçandu are mainly composed of low income classes, described as a set of individuals whose income does not allow them to reside in Maringá, thereby forcing them to live in the area surrounding the main city ${ }^{(9)}$.

Sarandi presents the highest number of hospitalizations among children younger than five years old and also characteristics similar to those found in the literature concerning risk factors for morbidity. It is also a source of workforce for the delivery of services for Maringá, which may hinder its own economic growth, reflected in the poor delivery of services, lower quality of life and marginalization of the population(9). Hence, there is a need to provide good health care coverage, and quality outpatient care, promoting quality of life, preventing diseases, and promoting health in order to reduce hospitalization rates and associated deleterious effects on the child and family. 
Maringá, in turn, has the lowest rate of hospitalization among children within the studied age group. It stands out because it is the main city and hosts the $15^{\text {th }}$ Health Region, a referral unit for most of the demand for health services in the neighboring cities. It presents income, economic growth, institutional organization, demography, and living conditions well above those observed in the conurbated cities.

This core-periphery model configured by Maringá (core) and Sarandi and Paiçandu (peripheral cities) also reflects on birth data, which was revealed by data analysis conducted by the Brazilian Live Birth Information System, SINASC(21). This report shows that regions in Sarandi and Paiçandu presented the worst socioeconomic indicators reflected by high percentages of adolescent mothers with a low level of education, and high birth rates among mixed and Afro-Brazilian individuals(21). Since diseases in the respiratory tract, more prevalent during childhood, present risk factors such as a low level of maternal education, it is important for the health staff to approach families with this characteristic, relate to them in a differentiated and efficient manner, providing clear and objective instructions concerning care to be provided to the sick child and also ensure access and quality of health care, factors that are essential to improving the participation and involvement of parents in the promotion of health and recovery of their children.

Based on the study's results and differences observed among the three cities, we note that the care provided by public agencies focused on primary prevention can be more efficient if already known risk factors are confronted ${ }^{(12)}$. Local management should pay special attention to the monitoring of hospitalizations given the possibility to structure primary health care and reorganize the local health system ${ }^{(22)}$.

The economic model influences the persistency of social inequalities and contributes to maintain the chain of events that culminates in child death due to evitable causes ${ }^{(23)}$. However, the prevention, diagnosis and early treatment of acute diseases, and the control and follow-up of chronic diseases, are able to reduce hospitalizations due to these conditions(15).

We also note the importance of taking into account the limitations of studies using secondary data such as the hospitalizations database, SUS-HIS. First, the magnitude of the hospitalization indicators may reflect the supply of hospital services and availability of human, material and technological resources in the studied cities. It is also important to bear in mind that there may be a variation in the SUS-HIS criteria defining causes of hospitalization over the time series analyzed in this study, as well as among the cities. Such a variation may be both a result of difficulties filling in information in the forms and underreporting of events.

Another characteristic of the SUS-HIS database is the non-existence of re-hospitalization records. There are multiple counts of hospitalizations for the same individual and also a repetition of diagnoses for the same individual, which may result in an overestimated number of hospitalizations ${ }^{(6)}$. We believe, however, that this last factor is not actually a limitation considering that the study's general objective was to describe the number, percentage and coefficient of hospitalizations in the population of children up to five years of age.

Even though there are considerations related to certain limitations faced when using secondary data and the SUS information systems, it is important to encourage the use of this information and train the health staff to correctly fill out documents that feed the system ${ }^{(24)}$. Such sensitization is important because the SUS databases are the source recommended by the Brazilian Ministry of Health to monitor child health indicators to plan health actions.

\section{Conclusion}

This study's results reveal a decline in the percentage of hospitalizations among children younger than five years old in the three studied cities in relation to the total hospitalizations in all age groups and also show that the risk of a child being hospitalized declined. Respiratory diseases are the most common cause of hospitalization followed by infectious and parasitic diseases. Another finding refers to differences observed among the cities. Higher percentages and hospitalization coefficients observed among children younger than five years old living in Sarandi and Paiçandu reveal differences in access to health services, in how appropriately primary health care is provided, and also socioeconomic differences in these populations compared to Maringá.

This study is expected to show how important it is to reflect upon and monitor hospitalizations due to evitable causes. It is crucial that nurses understand their role in preventing these occurrences and in the management and implementation of care plans during hospitalization and hospital discharge, analyzing not only technical aspects of the hospitalization process but also the impact of it on the life of the community. 


\section{References}

1. Malta DC, Sardinha LMV, Moura L, Sansky S, Leal MC, Szwarcwald $\mathrm{CL}$, et al. Atualização da lista de causas de mortes evitáveis por intervenções do Sistema Único de Saúde do Brasil. Epidemiol Serv Saúde. 2010;19(2):173-6.

2. Brasil. Conselho Nacional de Secretários de Saúde. Para entender o Pacto pela Saúde 2006, v. 1. Portaria GM/MS 399/2006. Brasília; 2006.

3. Caetano JRM, Bordin IAS, Puccini RF, Peres CA. Fatores associados à internação hospitalar de crianças menores de cinco anos, São Paulo, SP. Rev Saúde Pública. 2002;36(3):285-91.

4. Elias E, Magajewski F. A Atenção Primária à Saúde no sul de Santa Catarina. Rev Bras Epidemiol. 2008;11(4):633-47.

5. Ministério da Saúde (BR). Secretaria de Atenção à Saúde. Departamento de Atenção Básica (Série C. Projetos, Programas e Relatórios). Saúde da família no Brasil: uma análise de indicadores selecionados: 19982004. Brasília; 2006.

6. Ministério da Saúde (BR). Portaria no 493 de 13 de março de 2006. Aprova a Relação de Indicadores da Atenção Básica. Brasília; 2006.

7. Bittencourt AS, Camacho LAB, Leal MCO. Sistema de Informação Hospitalar e sua aplicação na saúde coletiva. Cad Saúde Pública. 2006;22(1):19-30.

8. Instituto Paranaense de Desenvolvimento Econômico e Social (BR). Caderno Estatístico. Município de Maringá. Maio 2011. [acesso 12 ago 2011]. Disponível em: http:// www.ipardes.gov.br/modules/conteudo/conteudo. php?conteudo $=5$.

9. Rodrigues AL. A ocupação urbana da região metropolitana de Maringá: uma história de segregação. Rev Parana Desenvolv. 2005;(108):61-86.

10. Ministério da Saúde (BR). DATASUS. [acesso 15 julho 2010]. Disponível em: http://tabnet.datasus.gov. $\mathrm{br} / \mathrm{cgi} /$ deftohtm.exe?sih/cnv/mrpr.def.

11. Mathias TAF, Soboll MLM. Confiabilidade de diagnósticos nos formulários de autorização de internação hospitalar. Rev Saúde Pública. 1998;32(6):526-32.

12. Macedo SEC, Menezes AMB, Albernaz E, Post $P$, Knorst $M$. Fatores de risco para internação por doença respiratória aguda em crianças até um ano de idade. Rev Saúde Pública. 2007;41(3):351-8.

13. Iwane KM, Edwards KM, Szilagyi PG, Walker FJ, Griffin $M R$, Weinberg MD, et al. Population-based surveillance for hospitalizations associated with Respiratory Synctyal Virus, Influenza Virus and Parainfluenza viruses among young children. Pediatrics. 2004;113(6):1758-64.
14. Oliveira BRG, Vieira CS, Collet N, Lima RAG. Causas de hospitalização no SUS de crianças de zero a quatro anos no Brasil. Rev Bras Epidemiol. 2010;13(2):268-77. 15. Alfradique ME, Bonolo PF, Dourado I, Lima-Costa MF, Macinko J, Mendonça CS, et al. Internações por condições sensíveis à atenção primária: a construção da lista brasileira como ferramenta para medir o desempenho do sistema de saúde (Projeto ICSAP-Brasil). Cad Saúde Pública. 2009;25(6):1337-49.

16. Coelho MF, Chaves LDP, Anselmi ML, Hayashida M, Santos CB. Análise dos aspectos organizacionais de um serviço de urgências clínicas: estudo em um hospital geral do município de Ribeirão Preto, SP, Brasil. Rev. Latino-Am. Enfermagem. 2010;18(4):770-7.

17. Victora CG, Aquino EML, Leal MC, Monteiro CA, Barros FC, Szwarcwald CL. Saúde de mães e crianças no Brasil: progressos e desafios. Lancet. 2011;32-46. doi:10.1016/S0140-6736(11)60138-4.

18. Victora CG. Diarrhea mortality: what can the world learn from Brazil? J Pediatria. 2009;85(1):3-5.

19. Bittencourt AS, Leal MC, Santos MO. Hospitalizações por diarréia infecciosa no Estado do Rio de Janeiro. Cad Saúde Pública. 2002;18(3):747-54. [acesso 12 ago 2010]. Disponível em: http://www.scielosp.org/pdf/csp/ v18n3/9302.pdf.

20. Mota AA. O que é a região metropolitana de Maringá: os múltiplos recortes espaciais e institucionais relacionados à cidade de Maringá. In: Rodrigues NA, Tonella C, organizadoras Retratos da Região Metropolitana de Maringá: subsídios para a elaboração de políticas públicas participativas. Maringá: Eduem; 2010. p. 41-65.

21. Predebon KM, Mathias TAF, Aidar T, Rodrigues AL. Desigualdade sócio-espacial expressa por indicadores do Sistema de Informações sobre Nascidos Vivos (SINASC). Cad Saúde Publica. 2010;26(8):1583-94.

22. Chaves LDP, Anselmi ML. Fatores explicativos para a variação na produção de internações hospitalares. Rev. Latino-Am. Enfermagem. 2008;16(2):287-92.

23. Molina RCM, Marcon SS, Uchimura TT, Lopes EP. Caracterização das internações em uma Unidade de Terapia Intensiva Pediátrica. Cienc Cuid Saúde. 2008;7(supl 1):112-20.

24. Soares ES, Menezes GMS. Fatores associados à mortalidade neonatal precoce. Epidemiol Serv Saúde. 2010;19(1):51-60.

Received: Mar. $15^{\text {th }} 2011$ Accepted: Dec. $19^{\text {th }} 2011$ 